\title{
The Role of Platelet Rich Plasma in the Treatment Algorithm of KneE OsteoARThRITIS
}

\author{
George C. Chang Chien, DO, Enrique Galang, MD, Richard Rosenthal, MD, and Aaron Calodney, MD
}

Osteoarthritis (OA) is a progressive joint disease associated with both mechanical and biologic abnormalities of the articular cartilage and subchondral bone. In normal cartilage, a delicate balance exists between matrix synthesis and degradation; in OA, however, cartilage degradation exceeds synthesis. Treatment modalities include nonpharmacological, pharmacological, and surgical approaches. Intrarticular platelet rich plasma (PRP) has emerged as promising treatment for early stages of knee OA.

PRP is an autologous blood product defined as a volume of plasma that has a supraphysiologic platelet count. PRP can accelerate the physiological recovery process, relieve pain, and contains anti-inflammatory and anti-bacterial activity. Although the mechanisms for these complex interactions are not completely understood, they are attributed to the more than 30 bioactive proteins contained in the alpha granules of platelets including growth factors and proteins, such as

Osteoarthritis (OA) is a progressive joint disease associated with both mechanical and biologic abnormalities of the articular cartilage and subchondral bone. In normal cartilage, a delicate balance exists between matrix synthesis and degradation; in OA, however, cartilage degradation exceeds synthesis. Although it may affect all joints, knee osteoarthritis is the most common type among adults, with a prevalence of $6 \%$ and a frequency reaching up to $40 \%$ with ad-

From : Ventura County Medical Center, Ventura, CA

Author for correspondence: George C. Chang Chien, DO

Address: Ventura County Medical Center, 3291 Loma Vista Rd., Ventura CA, 93003

E-mail: gchangchien@gmail.com fibrin, fibronectin, vitronectin and thrombospondin. Several studies now have demonstrated that intraarticular PRP injections are safe and effective treatment to reduce pain and improve quality of life through increased function in knee OA.

The available literature suggests that PRP is a better option than hyaluronic acid for many knee OA patients. We identified 12 comparative studies that demonstrated superiority of PRP as compared to hyaluronic acid for knee OA. Considering what is known about the deleterious effects of local anesthetic and corticosteroids on soft tissue health, it may be time for a shift in the knee OA treatment algorithm to favor early intervention for regenerative therapies including platelet rich plasma.

Key words: Platelet rich plasma, hyaluronic acid, knee pain, knee osteoarthritis, arthritis, chondrotoxicity

vancing age (1). Once articular cartilage is damaged, the healing potential is poor, subsequently leading to focal lesions of the cartilage and eventually OA.

Treatment modalities include non-pharmacological, pharmacological, and surgical approaches. Pharmacological approaches are often of limited benefit for OA pain; and serious side effects such as bleeding and gastrointestinal ulcers are associated with nonsteroidal anti-inflammatory drugs. Non-pharmacological approaches including intraarticular corticosteroid and viscosupplementation have demonstrated success resulting in improvements in pain, function, and quality of life. Intraarticular platelet rich plasma (PRP) has emerged as a promising treatment for early stages of knee OA. 
PRP is an autologous blood product defined as a volume of plasma that has a supra-physiologic platelet count. These platelets contain numerous growth factors stored in alpha granules. Thus, increased platelet count is a secondary measurement of growth factor concentration, which can be delivered to damaged tissues to promote healing. The autologous nature of PRP provides for a reduced risk profile as compared to potential side-effects associated with the use of hyaluronic acid injection (HA). The risks associated with some HA preparations include acute pseudo-septic arthritis and granulomatous synovitis (2). Although the optimal protocol for PRP injection in knee OA is yet to be determined, the general conclusion drawn from current literature is that intra-articular knee PRP is safe and effective (3). The current treatment algorithm for knee OA includes the injection of corticosteroid and local anesthetics. However, numerous studies have shown that both local anesthetic and corticosteroids can have deleterious effects on soft tissues including chondrocytes (4-7). This effect may potentiate acceleration of OA and clinically correlates with the observed effect of diminishing efficacy of repeat intraarticular injections.

HA is the only currently FDA approved for treatment of knee OA. HA is a natural component of the connective tissue and cartilage. HA contributes to the viscoelastic capacity of the synovial fluid, acting as both a lubricant and shock absorber. Although HA may also play a role in regeneration of cartilage tissue, the mechanism of $\mathrm{HA}$ in the cartilage after administration is not known. It is believed that the anti-nociceptive properties of $\mathrm{HA}$ are related to creating a boundary layer around nociceptors and reducing hyperalgesic, spontaneous discharge in the arthritic joint (8-11).

PRP can accelerate the physiological recovery process, relieve pain, and contains anti-inflammatory and anti-bacterial activity (11-13). Although the mechanisms for these complex interactions are not completely understood, they are attributed to the more than 30 bioactive proteins contained in the alpha granules of platelets including growth factors and proteins, such as fibrin, fibronectin, vitronectin, and thrombospondin (14).

Current best evidence supports the effectiveness of PRP in the treatment of tendon injuries (15). More recently, a growing body of evidence has accumulated examining PRP as a treatment of knee OA. Several studies now have demonstrated that intraarticular PRP injections are a safe and effective treatment to reduce pain and improve quality of life through increased function (16-22).

Multiple authors have sought to compare the efficacy of PRP to HA for knee OA. The results of these studies suggest the non-inferiority or superiority of PRP as compared to HA for knee OA (Table 1).

Sanchez et al (16) published a retrospective cohort study in 2008 on their experience with PRP compared to HA in knee OA. These authors reported on 60 patients (2 groups of 30 patients) matched according to age, gender, body mass index, and radiographic severity utilizing the Western Ontario and McMaster Universities Arthritis Index (WOMAC) as the primary outcome measure. When compared with the HA control group, the PRP group demonstrated a higher treatment success rate with greater pain functional improvements $(P=0.004)$.

In 2011, Kon et al (17) published a multicenter 3-arm prospective comparative study of 150 patients with unilateral Kellgren-Lawrence grades $1-4$ of knee OA. The outcomes of the study were measured with International Knee Documentation Committee (IKDC) and EuroQol visual analog scale (EQ-VAS) scores at 6 months. All 3 groups including the $2 \mathrm{HA}$ groups showed improvement; however, the PRP group showed statistically greater and longer-term improvements in pain and function at 2 and 6 months follow-up $(P<0.005)$.

In 2012, Spakova et al (18) published results of a randomized, double-blind controlled study on 120 patients with unilateral Kellgren-Lawrence grades $1-3$ knee OA. The outcomes of the study were measured with the WOMAC and the 11-point pain intensity numeric rating scale (NRS). One group received 3 intraarticular injections of PRP and the second group of patients received 3 injections of $\mathrm{HA}$. Between the HA and PRP groups, the PRP group had statistically improved WOMAC and NRS scores at 3 and 6 months follow-up $(P<0.01)$.

In 2012, Sanchez et al (19) reported the first doubleblinded, randomized controlled trial comparing the efficacy of PRP with HA in 176 patients with Ahlbäck grades $1-3$ disease of the knee. The 176 patients 
Table 1. Cohort studies and randomized controlled studies of platelet rich plasma injections for knee osteoarthritis.

\begin{tabular}{|c|c|c|c|c|c|c|c|c|}
\hline Authors & $\begin{array}{l}\text { Year } \\
\text { published }\end{array}$ & $\begin{array}{l}\text { Study } \\
\text { design }\end{array}$ & Patients & $\begin{array}{l}\text { Treatment } \\
\text { arms }\end{array}$ & $\begin{array}{l}\text { Outcome } \\
\text { measures }\end{array}$ & $\begin{array}{l}\text { Length of } \\
\text { follow-up }\end{array}$ & $\begin{array}{l}\text { Adverse } \\
\text { effects } \\
\text { to PRP } \\
\text { group }\end{array}$ & Results \\
\hline $\begin{array}{l}\text { Sanchez et } \\
\text { al (16) }\end{array}$ & 2008 & $\begin{array}{l}\text { Retrospective } \\
\text { cohort study }\end{array}$ & $\begin{array}{l}60 \text { patients } \\
60 \text { joints }\end{array}$ & $\begin{array}{l}\text { Group A ( } 30 \\
\text { joints), 3x PRP q } 1 \\
\text { week. } \\
\text { Group B ( } 30 \\
\text { joints), 3x HWHA } \\
\text { q } 1 \text { week. }\end{array}$ & WOMAC & 5 weeks & $\begin{array}{l}\text { No severe } \\
\text { adverse } \\
\text { events were } \\
\text { reported. }\end{array}$ & $\begin{array}{l}\text { PRP group } \\
\text { with better } \\
\text { pain outcomes } \\
\text { compared to HA } \\
\text { group. }\end{array}$ \\
\hline $\begin{array}{l}\text { Kon et al } \\
(17)\end{array}$ & 2011 & $\begin{array}{l}\text { Prospective } \\
\text { comparative } \\
\text { study }\end{array}$ & $\begin{array}{l}150 \text { patients } \\
150 \text { joints }\end{array}$ & $\begin{array}{l}\text { Group A ( } 50 \\
\text { joints), 3x PRP q } 2 \\
\text { weeks. } \\
\text { Group B ( } 50 \\
\text { joints), 3x HWHA } \\
\text { q } 2 \text { weeks. } \\
\text { Group C ( } 50 \\
\text { joints), 3x LWHA } \\
\text { q } 2 \text { weeks. }\end{array}$ & $\begin{array}{l}\text { EQ-VAS, } \\
\text { IKDC }\end{array}$ & 6 months & $\begin{array}{l}\text { No severe } \\
\text { adverse } \\
\text { events were } \\
\text { reported. }\end{array}$ & $\begin{array}{l}\text { PRP more } \\
\text { effective than HA } \\
\text { in patients aged } 50 \\
\text { years or younger } \\
\text { at } 6 \text { months. In } \\
\text { patients aged } 50 \\
\text { years or younger, } \\
\text { PRP and HA } \\
\text { showed equal } \\
\text { improvements. }\end{array}$ \\
\hline $\begin{array}{l}\text { Spakova et } \\
\text { al (18) }\end{array}$ & 2012 & $\begin{array}{l}\text { Randomized } \\
\text { double blind } \\
\text { controlled } \\
\text { trial }\end{array}$ & $\begin{array}{l}120 \text { patients } \\
120 \text { joints }\end{array}$ & $\begin{array}{l}\text { Group A ( } 60 \\
\text { joints), 3x PRP q } 1 \\
\text { week. } \\
\text { Group B ( } 60 \\
\text { joints), 3x HWHA } \\
\text { q 1week. }\end{array}$ & $\begin{array}{l}\text { NRS, } \\
\text { WOMAC }\end{array}$ & 6 months & $\begin{array}{l}\text { No severe } \\
\text { adverse } \\
\text { events were } \\
\text { reported. }\end{array}$ & $\begin{array}{l}\text { PRP group } \\
\text { with greater } \\
\text { improvement } \\
\text { in pain and } \\
\text { functional } \\
\text { outcomes } \\
\text { compared to HA } \\
\text { group. }\end{array}$ \\
\hline $\begin{array}{l}\text { Sanchez et } \\
\text { al (19) }\end{array}$ & 2012 & $\begin{array}{l}\text { Randomized } \\
\text { double blind } \\
\text { controlled } \\
\text { trial }\end{array}$ & $\begin{array}{l}176 \text { patients } \\
176 \text { joints }\end{array}$ & $\begin{array}{l}\text { Group A ( } 89 \\
\text { joints) 3x PRP q } 1 \\
\text { week. } \\
\text { Group B ( } 87 \\
\text { joints) 3x HWHA } \\
\text { q } 1 \text { week. } \\
\end{array}$ & $\begin{array}{l}\text { Responders } \\
\text { ( } 50 \% \text { pain } \\
\text { reduction), } \\
\text { WOMAC }\end{array}$ & 6 months & $\begin{array}{l}\text { No severe } \\
\text { adverse } \\
\text { events were } \\
\text { reported. }\end{array}$ & $\begin{array}{l}\text { PRP group had } \\
\text { more responders } \\
\text { ( } 50 \% \text { pain } \\
\text { reduction) when } \\
\text { compared to HA } \\
\text { group. }\end{array}$ \\
\hline $\begin{array}{l}\text { Cerza et al } \\
(20)\end{array}$ & 2012 & $\begin{array}{l}\text { Randomized } \\
\text { comparative } \\
\text { trial }\end{array}$ & $\begin{array}{l}120 \text { patients } \\
120 \text { joints }\end{array}$ & $\begin{array}{l}\text { Group A ( } 60 \\
\text { joints) 4x PRP q } 1 \\
\text { week. } \\
\text { Group B ( } 60 \\
\text { joints) 4x HWHA } \\
\text { q } 1 \text { week. }\end{array}$ & WOMAC & 6 months & $\begin{array}{l}\text { No severe } \\
\text { adverse } \\
\text { events were } \\
\text { reported. }\end{array}$ & $\begin{array}{l}\text { PRP group with } \\
\text { a longer duration } \\
\text { of improvements } \\
\text { when compared to } \\
\text { HA group. }\end{array}$ \\
\hline $\begin{array}{l}\text { Filardo et } \\
\text { al (21) }\end{array}$ & 2015 & $\begin{array}{l}\text { Randomized } \\
\text { double blind } \\
\text { controlled } \\
\text { trial }\end{array}$ & $\begin{array}{l}183 \text { patients } \\
183 \text { joints }\end{array}$ & $\begin{array}{l}\text { Group A (94 } \\
\text { joints) 3x PRP q } 1 \\
\text { week. } \\
\text { Group b ( } 89 \text { joints) } \\
\text { 3x HWHA q 1 } \\
\text { week. }\end{array}$ & $\begin{array}{l}\text { EQ- } \\
\text { VAS,IKDC, } \\
\text { KOOS, } \\
\text { Tegner }\end{array}$ & 12 months & $\begin{array}{l}\text { No severe } \\
\text { adverse } \\
\text { events were } \\
\text { reported. }\end{array}$ & $\begin{array}{l}\text { PRP and HA } \\
\text { provided } \\
\text { similar pain } \\
\text { and functional } \\
\text { outcomes. }\end{array}$ \\
\hline $\begin{array}{l}\text { Kilincoglu et } \\
\text { al (22) }\end{array}$ & 2015 & Retrospective & $\begin{array}{l}118 \text { patients } \\
199 \text { joints }\end{array}$ & $\begin{array}{l}\text { PRP group } 61 \\
\text { patients (102 } \\
\text { knees) HA group } \\
57 \text { patients ( } 97 \\
\text { knees) intra- } \\
\text { articular PRP or } \\
\text { HA treatments a } \\
\text { total of } 3 \text { times, } \\
\text { one week apart. }\end{array}$ & KSS, VAS & 3,6 months & $\begin{array}{l}\text { No severe } \\
\text { adverse } \\
\text { events were } \\
\text { reported. }\end{array}$ & $\begin{array}{l}\text { Intraarticular } \\
\text { PRP was more } \\
\text { efficient than HA } \\
\text { in the treatment } \\
\text { of early knee } \\
\text { osteoarthritis. }\end{array}$ \\
\hline
\end{tabular}


Table 1 cont. Cohort studies and randomized controlled studies of platelet rich plasma injections for knee osteoarthritis.

\begin{tabular}{|c|c|c|c|c|c|c|c|c|}
\hline Authors & $\begin{array}{l}\text { Year } \\
\text { published }\end{array}$ & $\begin{array}{l}\text { Study } \\
\text { design }\end{array}$ & Patients & $\begin{array}{l}\text { Treatment } \\
\text { arms }\end{array}$ & $\begin{array}{l}\text { Outcome } \\
\text { measures }\end{array}$ & $\begin{array}{l}\text { Length of } \\
\text { follow-up }\end{array}$ & $\begin{array}{l}\text { Adverse } \\
\text { effects } \\
\text { to PRP } \\
\text { group }\end{array}$ & Results \\
\hline $\begin{array}{l}\text { Raeissadat } \\
\text { et al (23) }\end{array}$ & 2015 & $\begin{array}{l}\text { Randomized } \\
\text { controlled } \\
\text { trial }\end{array}$ & $\begin{array}{l}160 \text { patients } \\
160 \text { joints }\end{array}$ & $\begin{array}{l}\text { PRP group (n } \\
=87) 2 \text { intra- } \\
\text { articular injections } \\
\text { at } 4 \text {-week interval. } \\
\text { HA group }(\mathrm{n}=73) \text {, } \\
3 \text { doses of intra- } \\
\text { articular injection } \\
\text { at } 1 \text {-week interval. }\end{array}$ & $\begin{array}{l}\text { WOMAC, } \\
\text { SF-36 }\end{array}$ & 12 months & $\begin{array}{l}\text { No severe } \\
\text { adverse } \\
\text { events were } \\
\text { reported. }\end{array}$ & $\begin{array}{l}\text { PRP group } \\
\text { demonstrated } \\
\text { superiority to the } \\
\text { HA group } \\
(P, 0.001)\end{array}$ \\
\hline $\begin{array}{l}\text { Lana et al } \\
(24)\end{array}$ & 2016 & $\begin{array}{l}\text { Multi-center, } \\
\text { randomized } \\
\text { controlled } \\
\text { double blind } \\
\text { prospective } \\
\text { trial }\end{array}$ & $\begin{array}{l}105 \\
\text { patients } \\
\text { with mild } \\
\text { to moderate } \\
\text { knee OA }\end{array}$ & $\begin{array}{l}\text { HA }(n=36), \\
\text { PRP }(n=36) \text {, or } \\
\text { HA+PRP }(n=33) .\end{array}$ & $\begin{array}{l}\text { WOMAC, } \\
\text { VAS }\end{array}$ & $\begin{array}{l}1,3,6 \text { and } \\
12 \text { months }\end{array}$ & $\begin{array}{l}\text { No severe } \\
\text { adverse } \\
\text { events } \\
\text { reported }\end{array}$ & $\begin{array}{l}\text { PRP group } \\
\text { with better } \\
\text { pain outcomes } \\
\text { compared to } \\
\text { HA group at all } \\
\text { intervals. HA + } \\
\text { PRP superior to } \\
\text { HA or PRP alone. }\end{array}$ \\
\hline $\begin{array}{l}\text { Paterson et } \\
\text { al (25) }\end{array}$ & 2016 & $\begin{array}{l}\text { Double-blind } \\
\text { randomized } \\
\text { controlled } \\
\text { pilot }\end{array}$ & $\begin{array}{l}23 \text { patients } \\
\text { with knee } \\
\text { OA }\end{array}$ & $\begin{array}{l}\text { PA-PRP }(n=12) \\
\text { HA }(n=11)\end{array}$ & $\begin{array}{l}\text { VAS, } \\
\text { KOOS, } \\
\text { KQoL, } \\
\text { maximum } \\
\text { hopping } \\
\text { distance, } \\
\text { knee bends }\end{array}$ & 4,12 weeks & $\begin{array}{l}\text { No severe } \\
\text { adverse } \\
\text { events } \\
\text { reported }\end{array}$ & $\begin{array}{l}\text { PA-PRP } \\
\text { significantly } \\
\text { improved } \\
\text { VAS, KOOS } \\
\text { Pain, KQoL } \\
\text { Physical, and } \\
\text { KQoL Emotional } \\
\text { subscales at } 4 \text { and } \\
12 \text { weeks. }\end{array}$ \\
\hline $\begin{array}{l}\text { Montañez- } \\
\text { Heredia et } \\
\text { al (26) }\end{array}$ & 2016 & $\begin{array}{l}\text { Double-blind } \\
\text { randomized } \\
\text { controlled } \\
\text { clinical trial }\end{array}$ & $\begin{array}{l}53 \text { patients } \\
\text { with knee } \\
\text { OA }\end{array}$ & $\begin{array}{l}\text { Leukocyte poor } \\
\text { PRP }(n=27) \text { HA } \\
(\mathrm{n}=26)\end{array}$ & $\begin{array}{l}\text { VAS, KOOS } \\
\text { scale, } \\
\text { EUROQOL }\end{array}$ & 3,6 months & $\begin{array}{l}\text { No severe } \\
\text { adverse } \\
\text { events } \\
\text { reported }\end{array}$ & $\begin{array}{l}\text { Both treatments } \\
\text { improved pain in } \\
\text { knee osteoarthritis } \\
\text { patients without } \\
\text { statistically } \\
\text { significant } \\
\text { differences } \\
\text { between them. } \\
\text { PRP injection was } \\
\text { demonstrated to be } \\
\text { more effective in } \\
\text { lower osteoarthritis } \\
\text { grades. }\end{array}$ \\
\hline $\begin{array}{l}\text { Cole et al } \\
(27)\end{array}$ & 2017 & $\begin{array}{l}\text { Randomized, } \\
\text { prospective } \\
\text { controlled } \\
\text { trial }\end{array}$ & $\begin{array}{l}99 \text { patients } \\
\text { with knee } \\
\text { OA }\end{array}$ & $\begin{array}{l}\text { PRP }(n=49) \text { HA } \\
(n=50)\end{array}$ & $\begin{array}{l}\text { WOMAC } \\
\text { pain } \\
\text { subscale, } \\
\text { IKDC, } \\
\text { subjective } \\
\text { knee } \\
\text { evaluation, } \\
\text { VAS for } \\
\text { pain, } \\
\text { Lysholm } \\
\text { knee score }\end{array}$ & $\begin{array}{l}12,24,52 \\
\text { weeks }\end{array}$ & $\begin{array}{l}\text { No severe } \\
\text { adverse } \\
\text { events } \\
\text { reported }\end{array}$ & $\begin{array}{l}\text { No difference } \\
\text { between the } \\
\text { groups in } \\
\text { WOMAC pain } \\
\text { score. } \\
\text { PRP group } \\
\text { demonstrated } \\
\text { lower VAS scores } \\
\text { at } 24 \text { and } 52 \\
\text { weeks. }\end{array}$ \\
\hline
\end{tabular}

IKDC = International Knee Documentation Committee; EQ-VAS $=$ EuroQol visual analog scale; KOOS $=$ Knee Injury and Osteoarthritis Outcome Scores; PRP $=$ platelet-rich plasma; WOMAC = Western Ontario and McMaster Universities Arthritis Index; NRS = Numeric Rating Scale; SF 36 = Short Form 36; KSS = Knee Society's Knee Scoring System 
with symptomatic knee arthritis were randomized to receive injections of PRP or with HA. The primary outcome measure was a $50 \%$ decrease of knee pain from baseline to 6 months. Secondary outcomes were also measured using the WOMAC. Although not statistically significant, at 6 months the rate of response was 14.1 percentage points higher in the PRP group than in the HA group $(P=0.44)$. Furthermore, the rate of response defined as greater than $50 \%$ reduction in pain between the 2 groups showed opposite patterns, with a substantial improvement of the primary outcome in the PRP group at 24 weeks while the HA group revealed a gradual decline.

In 2012, Cerza et al (20) compared PRP with HA in 120 randomized patients with Kellgren-Lawrence grades $1-3$ of knee OA. The 120 patients were randomized into a $1: 1$ ratio with one group receiving 4 intraarticular PRP injections and the other group 4 intraarticular HA injections. The outcomes were measured using the WOMAC before the injection and at one month, 3 months, and 6 months after the first injection. Compared to the HA group, the PRP had statistically better WOMAC scores at one month, 3 months, and 6 months follow-up $(P<0.001)(20)$. In addition, in patients with Kellgren-Lawrence grade 3 arthritis, treatment with HA was decidedly less effective than treatment with PRP.

Filardo et al (21) in 2015 published a randomized controlled trial of 192 patients comparing the benefit of PRP to HA. Patients underwent 3 weekly intraarticular injections of either PRP or HA. The outcomes of the study were measured using the International Knee Documentation Committee (IKDC) subjective score, as well as the Knee Injury and Osteoarthritis Outcome Score (KOOS), EQ-VAS, and Tegner score. Both treatments proved to be effective in reducing symptoms and improving functional status. The IKDC score in the PRP group rose from $52.4 \pm 14.1$ to 66.2 \pm 16.7 at 12 months $(P<0.0005)$. On the other hand, the IKDC score of the HA group rose from $49.6 \pm$ 13.0 to $64.2 \pm 18.0$ at 12 months $(P<0.0005)$. In addition, in the HA group, 2 patients reported severe pain and swelling while the PRP group had no major adverse events.

Kilincoglu et al (22) in 2015 reported results of 118 patients with Kellgren-Lawrence stage 1 and 2 of knee OA in a retrospective study comparing PRP and
HA (22). The patients received intraarticular injections of PRP or HA for a total of 3 treatments, one week apart. The patients were evaluated using the Knee Society's Knee Scoring System (KSS) and the VAS scoring system before the treatment and at 3 and 6 months after the treatment. At 3 months and 6 months post treatment, the PRP group had significantly improved KSS $(P<0.001)$ and VAS $(P<0.001)$.

Also in 2015, Raeissdat et al (23) published a randomized controlled trial comparing the efficacy of PRP with HA in 180 patients with grade $1-4$ KellgrenLawrence scale of knee OA. In the PRP group, 2 intraarticular injections at 4-week intervals were performed, and in the HA group, 3 doses of intraarticular injection at one-week intervals were performed. All patients were evaluated prior to treatment and at 12 months using the WOMAC and Short Form (SF)-36 questionnaires. At 12 month follow-up, both groups had improved WOMAC pain scores and bodily pain; however, the PRP group had better results compared to the HA group $(P<0.001)$.

Lana et al (24) published the results of a 2016 multi-center, randomized, controlled, double blind, prospective trial comparing hyaluronic acid, plateletrich plasma and the combination of both in the treatment of mild and moderate osteoarthritis of the knee. the study randomly allocated 105 patients with mild to moderate knee OA to HA ( $n=36)$, PRP $(n=36)$, or HA+PRP $(n=33)$. Each patient received 3 intraarticular knee injections of their assigned substance, at 2 week intervals. Clinical outcomes were evaluated using the WOMAC and VAS questionnaire at baseline and after 1, 3, 6 and 12 months. The PRP group demonstrated significant reduction in VAS scores at all follow up intervals when compared to HA. Combining HA and PRP resulted in a significant decreases in pain $(P=0.0001)$ and functional limitation $(P=$ 0.0001 ) when compared to HA alone at 1 year post treatment; and significantly increased physical function at $1(P=0.0004)$ and $3(P=.011)$ months when compared to PRP alone.

In 2016, Paterson et al (25) published the results of a double-blind randomized controlled pilot comparing photo-activated PRP (PA-PRP) to HA in people with knee OA. Twelve subjects were randomized to the PA-PRP group and 11 to the HA group. Outcomes included recruitment and safety data, VAS, the 
KOOS, KQoL scale, and maximum hopping distance and number of knee bends in 30 seconds, at 4 and 12 weeks. two participants from the PA-PRP group reported minor pain and swelling from the injections. The PA-PRP group demonstrated significant improvements in the VAS $(P<0.01$, ETA $=0.686)$, KOOS Pain $(P<0.05$, ETA $=0.624)$, KQoL Physical $(P<0.05, \mathrm{ETA}=0.706)$ and KQoL Emotional subscales $(P<0.05$, ETA $=0.715)$ at 4 and 12 weeks. The PA-PRP group also significantly improved hoping $(P<0.05, \mathrm{ETA}=0.799)$ and knee bends $(P<0.01$, $\mathrm{ETA}=0.756)$ at 4 or 12 weeks. The HA group showed improvements on only the KOOS Function subscale at 12 weeks $(P<0.01$, ETA $=0.602)$. After controlling for baseline values, there were no significant between-group differences at either time-point.

Also in 2016, Montañez-Heredia et al (26) published the results of a double-blind randomized controlled clinical trial to evaluate the efficacy of injecting autologous PRP versus HA in knee OA. There were 27 patients randomized to PRP and 26 patients randomized to HA completed the trial. PRP group patients were injected with PRP rich in platelets and weak in leukocytes and red blood cells. Pain and functional improvements were assessed pre- and post-treatment at, 3 and 6 months follow-up using VAS; the KOOS scale and the EUROQOL. Adverse events in both groups did not show significant differences. There was pain related to infiltration in nine of 27 PRP injections and in 4 of 26 for HA. Both groups presented pain reduction at 6 months. The VAS scores for the PRP group improved by at least $50 \%$ from their initial value, particularly at 3 months following the final infiltration, with results resembling those of the HA group at 6 months. PRP was more effective in patients with lower osteoarthritis grades. Both treatments improved pain in knee osteoarthritis patients without statistically significant differences between them. PRP injection was demonstrated to be more effective in lower osteoarthritis grades.

In 2017 Cole et al (27) published the results of a randomized controlled trial comparing hyaluronic acid and platelet-rich plasma injection for knee OA. 49 patients were randomized to treatment with PRP and 50 randomized to treatment with $\mathrm{HA}$. Clinical data were collected before treatment and at 4 time points up to 52 weeks. Outcome measures were WOMAC pain subscale, IKDC, subjective knee evaluation, VAS for pain, Lysholm knee score, and difference in intra-articular biochemical marker concentrations. No difference was seen between the groups in WOMAC pain score. There were significantly higher IKDC score in the PRP group compared with the HA group at 24 weeks $(P=.013)$ and at final follow-up (52 weeks) $(P=.003)$. The PRP group demonstrated lower VAS scores at $24(P=.0096)$ and 52 weeks $(P=.0039)$.

Since PRP is obtained from the patients' own blood, immune reaction or blood-borne diseases are highly unlikely to occur. No serious side effects or complications were demonstrated regarding administration of PRP in any of the studies. Considering what is known about the deleterious effects of local anesthetic and corticosteroids on soft tissue health, it may be time for a shift in the knee OA treatment algorithm to favor early intervention for regenerative therapies including platelet rich plasma with or without hyaluronic acid.

\section{REFERENCES}

1. Michael JW, Schlüter-Brust KU, Eysel P. The epidemiology, etiology, diagnosis and treatment of osteoarthritis of the knee. Dtsch Arztebl Int 2010; 107:152-162.

2. Weinrauch P, Trigger R, Tsikleas G. Bilateral hip joint hylan G-F 20 granulomatous synovitis due to viscosupplementation injections. Case Reports in Orthopedics 2014; 2014:1-4.

3. Pourcho AM, Smith J, Wisniewski SJ, Sellon JL. Intraarticular platelet-rich plasma injection in the treatment of knee osteoarthritis: Review and recommendations. AmJ Phys Med Rehabil 2014; 93:S108-S121.

4. Maeda T, Toyoda F, Imai S, Tanigawa H, Kumagai, Matsuura

$\mathrm{H}$, Matsusue $\mathrm{Y}$. Lidocaine induces ROCK-dependent membrane blebbing and subsequent cell death in rabbit articular chondrocytes. J Orthop Res 2016; 34:754-762.

5. Sherman SL, Khazai RS, James $\mathrm{CH}$, Stoker AM, Flood DL, Cook JL. In vitro toxicity of local anesthetics and corticosteroids on chondrocyte and synoviocyte viability and metabolism. Cartilage 2015; 6:233-240.

6. Dragoo JL, Danial CM, Braun HJ, Pouliot MA, Kim HJ. The chondrotoxicity of single-dose corticosteroids. Knee Surg Sports Traumatol Arthrosc 2012; 20:1809-1814.

7. Braun HJ, Wilcox-Fogel N, Kim HJ, Pouliot MA, Harris AH, Dragoo JL. The effect of local anesthetic and corticosteroid combinations on chondrocyte viability. Knee Surg Sports Traumatol 
Arthrosc 2012;20:1689-1695.

8. Balazs E. The physical properties of synovial fluid and the specific role of hyaluronic acid. In: Helfet AJ (ed). Disorders of the Knee. 2nd ed. JB Lippincott, Philadelphia, PA, 1982, pp 61-74.

9. Gotoh S, Miyazaki K, Onaya J, Sakamoto T, Tokuyasu T, Namiki O. Experimental knee pain model in rats and analgesic effect of sodium hyaluronate (SPH) [in Japanese]. Nippon Yakurigaku Zasshi 1988; 92:17-27.

10. Pozo MA, Balazs EA, Belmonte C. Reduction of sensory responses to passive movements of inflamed knee joints by hylan, a hyaluronan derivative. Exp Brain Res 1997; 116:3-9.

11. Trojian TH, Concoff AL, Joy SM, Hatzenbuehler JR, Saulsberry WJ, Coleman Cl. AMSSM scientific statement concerning viscosupplementation injections for knee osteoarthritis: Importance for individual patient outcomes. Clin J Sport Med 2016; 26:1-11.

12. Cox D, Kerrigan SW, Watson SP. Platelets and the innate immune system: Mechanisms of bacterial-induced platelet activation. J Thromb Haemost 2011; 9:1097-1107.

13. Davis VL, Abukabda AB, Radio NM, Witt-Enderby PA, Clafshenkel WP, Cairone JV, Rutkowski JL. Platelet-rich preparations to improve healing. Part II: Platelet activation and enrichment, leukocyte inclusion, and other selection criteria. J Oral Implantol 2014; 40:511-521.

14. Anitua E, Andia I, Ardanza B, Nurden P, Nurden AT. Autologous platelets as a source of proteins for healing and tissue regeneration. Thromb Haemost 2004; 91:4-15.

15. Murray DJ, Javed S, Jain N, Kemp S, Watts AC. Platelet-richplasma injections in treating lateral epicondylosis: A review of the recent evidence. $J$ Hand Microsurg 2015; 7:320-325.

16. Sanchez M, Anitua E, Azofra J, Aguirre JJ, Andia I. Intraarticular injection of an autologous preparation rich in growth factors for the treatment of knee OA: A retrospective cohort study. Clin Exp Rheumatol 2008; 26:910-913.

17. Kon E, Mandelbaum B, Buda R, Filardo G, Delcogliano M, Timoncini A, Fornasari M, Giannini S, Marcacci M. Platelet-rich plasma intra-articular injection versus hyaluronic acid viscosupplementation as treatments for cartilage pathology: From early degeneration to osteoarthritis. Arthroscopy 2011; 27:1490-1501.

18. Spaková T, Rosocha J, Lacko M, Harvanová D, Gharaibeh A. Treatment of knee joint osteoarthritis with autologous plateletrich plasma in comparison with hyaluronic acid. Am J Phys Med Rehabil 2012; 91:411-417.

19. Sanchez M, Fiz N, Azofra J, Usabiaga J, Aduriz Recalde E, Gar- cia Guitierrez A, Albillos J, Garate R, Aguirre JJ, Padilla S, Orive $\mathrm{G}$, Anitua $\mathrm{E}$. A randomized clinical trial evaluating plasma rich in growth factors (PRGF-Endoret) versus hyaluronic acid in the short-term treatment of symptomatic knee osteoarthritis. Arthroscopy 2012; 28:1070-1078.

20. Cerza F, Carni S, Carcangiu A, Di Vao I, Schiavilla V, Pecora A, De Biasi G, Ciuffreda M. Comparison between hyaluronic acid and platelet-rich plasma, intra-articular infiltration in the treatment of gonarthrosis. Am J Sports Med 2012; 40:2822-2827.

21. Filardo G, Di Matteo B, Di Martino A, Merli ML, Cenacchi A, Fornasari P, Marcacci M, Kon E. Platelet-rich plasma intra-articular knee injections show no superiority versus viscosupplementation: A randomized controlled trial. Am J Sports Med 2015; 43:1575-1582.

22. Kilincoglu V, Yeter A, Servet E, Kangal M, Yildirim M. Short term results comparison of intraarticular platelet-rich plasma (prp) and hyaluronic acid (ha) applications in early stage of knee osteoarthritis. Int J Clin Exp Med 2015; 8:18807-18812.

23. Raeissadat SA, Rayegani SM, Hassanabadi H, Fathi M, Ghorbani E, Babaee M, Azma K. Knee osteoarthritis injection choices: Platelet-rich plasma (PRP) versus hyaluronic acid (A oneyear randomized clinical trial). Clin Med Insights Arthritis Musculoskelet Disord 2015; 8:1-8.

24. Lana JF, Weglein A, Sampson SE, Vicente EF, Huber SC, Souza CV, Ambach MA, Vincent $\mathrm{H}$, Urban-Paffaro A, Onodera CM, Annichino-Bizzacchi JM, Santana MH, Belangero WD. Randomized controlled trial comparing hyaluronic acid, plateletrich plasma and the combination of both in the treatment of mild and moderate osteoarthritis of the knee. J Stem Cells Regen Med 2016;12:69-78.

25. Paterson KL, Nicholls M, Bennell KL, Bates D. Intra-articular injection of photo-activated platelet-rich plasma in patients with knee osteoarthritis: a double-blind, randomized controlled pilot study. BMC Musculoskelet Disord 2016;17:67.

26. Montañez-Heredia E, Irízar S, Huertas PJ, Otero E, Del Valle M, Prat I, Díaz-Gallardo MS, Perán M, Marchal JA, Hernandez-Lamas Mdel C. Intra-articular injections of platelet-rich plasma versus hyaluronic acid in the treatment of osteoarthritic knee pain: A randomized clinical trial in the context of the Spanish $\mathrm{Na}$ tional Health Care System. Int J Mol Sci 2016 2; 17. pii: E1064.

27. Cole BJ, Karas V, Hussey K, Pilz K, Fortier LA. Hyaluronic acid versus platelet-rich plasma. Am J Sports Med 2017; 45:339-346. 
